\title{
Development of Learning Video with Open Ended Approach to Improve Ability Mathematical Reasoning and Critical Thinking Students of High School of High School of Muslimin Medan in Medan
}

\author{
Mia Yolanda Siregar, Hasratuddin, Hermawan Syahputra \\ Medan State University Postgraduate
}

\begin{abstract}
This research was conducted in two stages, namely the first stage of developing learning videos with the Open Ended approach using the ADDIE development model, and the second stage testing the learning videos with the Open Ended approach which was developed in grades VIII-1 and VIII-2 SMP Ikhwanul Muslimin Medan. From the results of the first and second trials, it was obtained: 1) In the first and second trials there was an increase in the average value of students' mathematical reasoning abilities of $14.64 ; 2$ ) In the first and second trials there was an increase in the average value of students' mathematical critical thinking skills of 7.29; 3) Learning videos with an Open Ended approach to improve mathematical reasoning and critical thinking skills have been effective to use;
\end{abstract}

Keywords: development of learning videos, ADDIE model, Open Ended Approach, mathematical reasoning, mathematical critical thinking.

DOI: $10.7176 / \mathrm{JEP} / 12-16-05$

Publication date:June $30^{\text {th }} 2021$

\section{PRELIMINARY}

The development of science and technology in the 21 st century is growing rapidly. In addition to growing rapidly, changes also occur rapidly. If it is not balanced, Indonesia will be left behind from other countries. There are many things that are at the root of this, one of which is the increasingly strong and open current of globalization. Education is one of the means so that Indonesia does not lag behind other countries. This is in line with Pratama, Syahputra H (2017) "Education is the pillar of the nation's livelihood. Thanks to education, this nation can maintain its dignity." Education has become a pillar of increasing Indonesia's human resources for nation building.

Mathematics is one of the main subjects in every level of education. According to Hasratuddin (2018), mathematics is a tool used to develop and grow the ability to think logically, think critically, and systematically in a person. According to Simamora, RE, Saragih, S., \& Hasratuddin (2018), that "The vision of mathematics education today is to master the concepts used in learning mathematics, which are used to solve problems. One of the abilities that must be possessed by students in learning mathematics is the ability to reason mathematically. This is in accordance with the five aspects of mathematical ability as formulated by the National Council of Teachers of Mathematics (NCTM) (2000) including: "(1) mathematical communication; (2) mathematical reasoning (mathematical reasoning); (3) mathematical problem solving (mathematical problem solving); (4) mathematical connection (mathematical connection); and (5) mathematical representation". The importance of reasoning ability in mathematics learning according to Suryadi, A (2005), learning which emphasizes more on reasoning and problem solving activities is closely related to high student achievement. Mathematical reasoning (Rizqi, NR, Surya, E, 2017) is the basis for acquiring or building mathematical knowledge. Using reasoning in patterns and characters, performing mathematical manipulations in making generalizations, compiling proofs, or explaining mathematical ideas and statements are important things to improve students' reasoning abilities about mathematical material. (3) mathematical problem solving (mathematical problem solving); (4) mathematical connection (mathematical connection); and (5) mathematical representation". The importance of reasoning ability in mathematics learning according to Suryadi, A (2005), learning which emphasizes more on reasoning and problem solving activities is closely related to high student achievement. Mathematical reasoning (Rizqi, NR, Surya, E, 2017) is the basis for acquiring or building mathematical knowledge. Using reasoning in patterns and characters, performing mathematical manipulations in making generalizations, compiling proofs, or explaining mathematical ideas and statements are important things to improve students' reasoning abilities about mathematical material. (3) mathematical problem solving (mathematical problem solving); (4) mathematical connection (mathematical connection); and (5) mathematical representation". The importance of reasoning ability in mathematics learning according to Suryadi, A (2005), learning which emphasizes more on reasoning and problem solving activities is closely related to high student achievement. Mathematical reasoning (Rizqi, NR, Surya, E, 2017) is the basis for acquiring or building mathematical knowledge. Using reasoning in patterns and characters, performing mathematical manipulations in making generalizations, compiling proofs, or explaining 
mathematical ideas and statements are important things to improve students' reasoning abilities about mathematical material. (4) mathematical connection (mathematical connection); and (5) mathematical representation". The importance of reasoning ability in mathematics learning according to Suryadi, A (2005), learning which emphasizes more on reasoning and problem solving activities is closely related to high student achievement. Mathematical reasoning (Rizqi, NR, Surya, E, 2017) is the basis for acquiring or building mathematical knowledge. Using reasoning in patterns and characters, performing mathematical manipulations in making generalizations, compiling proofs, or explaining mathematical ideas and statements are important things to improve students' reasoning abilities about mathematical material. (4) mathematical connection (mathematical connection); and (5) mathematical representation". The importance of reasoning ability in mathematics learning according to Suryadi, A (2005), learning which emphasizes more on reasoning and problem solving activities is closely related to high student achievement. Mathematical reasoning (Rizqi, NR, Surya, E, 2017) is the basis for acquiring or building mathematical knowledge. Using reasoning in patterns and characters, performing mathematical manipulations in making generalizations, compiling proofs, or explaining mathematical ideas and statements are important things to improve students' reasoning abilities about mathematical material. The importance of reasoning ability in mathematics learning according to Suryadi, A (2005), learning which emphasizes more on reasoning and problem solving activities is closely related to high student achievement. Mathematical reasoning (Rizqi, NR, Surya, E, 2017) is the basis for acquiring or building mathematical knowledge. Using reasoning in patterns and characters, performing mathematical manipulations in making generalizations, compiling proofs, or explaining mathematical ideas and statements are important things to improve students' reasoning abilities about mathematical material. The importance of reasoning ability in mathematics learning according to Suryadi, A (2005), learning which emphasizes more on reasoning and problem solving activities is closely related to high student achievement. Mathematical reasoning (Rizqi, NR, Surya, E, 2017) is the basis for acquiring or building mathematical knowledge. Using reasoning in patterns and characters, performing mathematical manipulations in making generalizations, compiling proofs, or explaining mathematical ideas and statements are important things to improve students' reasoning abilities about mathematical material. NR, Surya, E, 2017) is the basis for acquiring or building mathematical knowledge. Using reasoning in patterns and characters, performing mathematical manipulations in making generalizations, compiling proofs, or explaining mathematical ideas and statements are important things to improve students' reasoning abilities about mathematical material. NR, Surya, E, 2017) is the basis for acquiring or building mathematical knowledge. Using reasoning in patterns and characters, performing mathematical manipulations in making generalizations, compiling proofs, or explaining mathematical ideas and statements are important things to improve students' reasoning abilities about mathematical material.

In fact, students' mathematical reasoning abilities are low. The low ability of students' mathematical reasoning will affect the quality of student learning, so it has an impact on their low academic achievement in school. Based on observations at SMP IT Ikhwanul Muslimi, the class is less conducive in the learning process, students tend to be passive in learning, and students are less directed to problems to improve mathematical reasoning. This is supported by student learning outcomes which are implied in the results of research conducted by Sumarmo in Sukirwan (2008) which shows that students' understanding and reasoning abilities are still low.

In addition to students' mathematical reasoning abilities, critical thinking skills are also very much needed by students in learning mathematics at school. Kurniasih (2012) Mathematical critical thinking will make students able to organize and combine mathematical thinking through communication, communicate mathematical thinking coherently and clearly to other students, teachers and others, analyze and evaluate mathematical thinking and strategies, use mathematical language to express ideas - Mathematical ideas correctly, in addition to the critical thinking skills possessed by students in learning mathematics, it is very necessary to understand and solve a mathematical problem or problem that requires reasoning, analysis, evaluation and interpretation of thoughts.

This is a fact that proves that students' reasoning and critical thinking abilities are still low. Students' mathematical reasoning and critical thinking abilities are still low because students still rarely train themselves to solve problems. In addition, it can also be concluded that students do not understand the meaning of the question and do not understand the mathematical concepts that can be used. Students do not understand how to make a mathematical model of the problems presented. The ability of mathematical reasoning and critical thinking of students seems still far from expectations. Apart from the inability of students to apply mathematical concepts in everyday problems, another cause is the lack of media in the mathematics learning process.

The explanation that has been explained previously shows how important the students' reasoning and critical thinking skills are in the teaching and learning process of mathematics. However, it is very unfortunate that in field observations, teachers have not packaged learning optimally because in the mathematics learning process teachers still only use the lecture method, then the learning environment is not conducive, so learning is less fun, and the lack of student participation in learning.

The above is in accordance with Hasratuddin's (2018) statement and in line with these findings, Afifah, IN 
Sudargo \& Prasetyowati, D. (2019) that the reality on the ground is that there are still many teachers who adhere to the transfer of knowledge paradigm in learning, which does not require mental activity. students. The lion's share of mathematics learned in school is not acquired through mathematical exploration, but through notice. So that the decline in students' abilities in mathematics is partly due to the way teachers teach still uses inappropriate learning through conventional models, emphasizing more on practicing questions or drills.

To overcome problems in learning, it is necessary to change the approach in learning mathematics, namely an approach that provides opportunities for students to be active in learning mathematics. One of them is the Open Ended approach. The open-ended approach (Novitar, C \& Aripin, U, 2017) is one approach in learning that begins by giving a problem to students, where the problem has more than one correct solution and answer. The open-ended approach is also interpreted as one of the learning approaches in which educators present a problem for students whose solutions or answers to problems are obtained in various ways.

The advantages of the open-ended approach, according to Sawada (1997) are: 1) Students can play a more active role, 2) Students have wider opportunities to apply their mathematical knowledge and abilities more comprehensively, 3) Provide wider opportunities, especially for students whose achievements less to be able to solve problems using their own way, 4) students are intrinsically motivated to be able to provide evidence, 5) provide opportunities for students to gain more experience to find effective ways to solve problems with the help of students' ideas other.

Based on research, especially mathematics education, it shows that the Open Ended approach is able to be a solution to overcome problems in an effort to improve students' reasoning and critical thinking skills according to research conducted by Arfan S, Abdullah IH, Bani A (2019), which results that learning with an open approach -Ended has an effect on increasing students' mathematical reasoning abilities. Factors that affect students' low mathematics are internal factors and external factors. Internal factors where the learning process has not been maximized both from the use of models and approaches and external factors where learning media are not adequate and external factors, namely learning media in schools are not adequate.

In an effort to improve students' mathematical reasoning and critical thinking skills, we need a learning method and a conducive environment for the development of these abilities. So that learning can stimulate students to learn independently, be creative, and be more active in participating in learning activities. There is a lot of software created for human commercial needs and it can be turned into learning media. One of the software that the researcher will use is Wondershare Filmora 9. After studying the making of learning media in Wondershare Filmora 9. The researcher is interested in making learning media to help the teaching and learning process more fun and effective and efficient. Wondershare Filmora is a software used to make home movies,

\section{RESEARCH METHODS}

This type of research used the Research and Development (R\&D) method. Research and Development is one of the research methods applied to produce a product as well as to test the validity, practicality and effectiveness of the resulting product, so that it is feasible to use. This development research aims to produce a new product that already exists and will be developed again. In this research and development, the researcher applies the ADDIE model. This ADDIE model consists of five steps in its application, namely: (1) analysis, (2) design, (3) development, implementation and (5) evaluation. .

The product developed from this research is a learning video with an open-ended approach to cube and block material to improve mathematical reasoning and critical thinking skills.

This research was carried out at the IT Ikhwanul Muslimin Middle School in the even semester of the 2020/2021 school year.The implementation time of this research is planned in April-May 2021. The subjects in this study were Class VIII students at SMP IT Ikhwanul Muslimin for the 2020/2021 academic year. While the object in this study is a learning video with an open ended approach to improve students' mathematical reasoning and critical thinking skills on cube and block material.

\section{RESEARCH RESULT}

This research is a development research, so the product of this research is a learning video. The purpose of this development research is to describe: (1)improving students' mathematical reasoning skills using learning videos with an Open Ended approach; (2)improving students' mathematical critical thinking skills using learning videos with an Open Ended approach; and (3)quality learning videos with an Open Ended approach to improve students' mathematical reasoning and critical thinking skills (4) differences in students' mathematical reasoning and critical thinking abilities who are taught using learning videos with an Open Ended approach with students' mathematical reasoning and critical thinking abilities taught with ordinary learning. To achieve this goal, a development research was carried out using the ADDIE model which was previously described in Chapter III. Data analysis and research results obtained in each stage of development are presented as follows:

\section{a. Item Validity Test Results}

The validity of the questions was analyzed using the SPSS 22 application. UPosttest research instrument trial of 
reasoning ability for 3 essay questions and students' mathematical critical thinking for 4 essay questions with a significant level of $5 \%, \mathrm{dk}=28$, obtained rtable $=0.361$ if referring to the test criteria, with the test criteria being rcount $>$ rtable then the ability test mathematical reasoning and critical thinking can be used or valid. Thus, based on the calculations carried out with the help of the SPSS 22 application, it is concluded that the test of reasoning ability and mathematical critical thinking ability can be used or valid.

Table 1.1. Calculation of the Validity of the Posttest Items of Students' Mathematical Reasoning Ability Using Excel

\begin{tabular}{|c|l|l|c|c|}
\hline No & $\boldsymbol{r}_{\boldsymbol{x y}}$ & $\boldsymbol{t}_{\text {hitung }}$ & $\boldsymbol{t}_{\text {tabel }}$ & Interpretation \\
\hline 1 & 0,906 & 11,355 & 2.048 & Significant/Valid \\
\hline 2 & 0,946 & 15,517 & 2.048 & Significant/Valid \\
\hline 3 & 0,953 & 16,623 & 2.048 & Significant/Valid \\
\hline
\end{tabular}

Based on Table 4.9. The above is a posttest test of students' mathematical reasoning abilities for 3 essay questions with a significant level of $5 \%, \mathrm{dk}=28 \mathrm{obtained} \mathrm{ttable}=2.048$.If it refers to the test criteria, with the test criteria being tcount $>$ ttable, the posttest of students' mathematical reasoning abilities can be used or is valid. Thus, based on calculations performed with excel and spss, it is concluded that the students' mathematical reasoning ability test can be used or is valid.

Table 1.2. Calculation of the Validity of the Posttest Items of Students' Mathematical Critical Thinking Ability Using Excel

\begin{tabular}{|c|l|l|c|l|}
\hline No & $\boldsymbol{r}_{\boldsymbol{x y}}$ & $\boldsymbol{t}_{\text {hitung }}$ & $\boldsymbol{t}_{\text {tabel }}$ & Interpretation \\
\hline 1 & 0,931 & 13,531 & 2.048 & Significant/Valid \\
\hline 2 & 0,877 & 9,665 & 2.048 & Significant/Valid \\
\hline 3 & 0,898 & 10,771 & 2.048 & Significant/Valid \\
\hline 4 & 0.841 & 8,223 & 2.048 & Significant/Valid \\
\hline
\end{tabular}

Based on Table 4.10 in above is a posttest test of students' mathematical critical thinking skills for 4 essay questions with a significant level of $5 \%, \mathrm{dk}=28$, obtained ttable $=2,048$. If referring to the test criteria, the test criteria is tcount $>\mathrm{t}$ table then the posttest of students' mathematical critical thinking skills can be used or valid. Thus, based on calculations performed with excel and spss, it is concluded that the students' mathematical critical thinking ability test can be used or valid.

\section{b. Item Reliability Test Results}

The reliability of the instrument is used to determine the determination of the test results. After calculating the reliability of the reasoning ability test of 0.930 and mathematical critical thinking ability of 0.910 with a very high category. Furthermore, the instrument was applied during trial I and trial II. Trials I and II were also carried out to describe the impact of using learning videos using the Open Ended Approach in seeing the improvement of mathematical reasoning and critical thinking skills from trial I to trial II.

c. Hypothesis test

Testing this hypothesis aims to determine the difference between mathematical reasoning abilities and mathematical critical thinking taught with the Open Ended approach with ordinary learning in the learning of cubes and blocks for class VIII SMP Ikhwanul Muslimin Medan. The analysis used is a t-test with the help of SPSS for windows version 22 which can be explained in detail as follows:

\section{Mathematical Reasoning Ability t-test}

The summary of the t-test of reasoning abilities taught with the Open Ended approach with reasoning abilities with ordinary learning is shown in Table 4.44. following:

\section{Table 1.3. Summary of Mathematical Reasoning Ability t Test Results}

\begin{tabular}{|l|c|c|c|c|}
\hline \multicolumn{1}{|c|}{ Class } & Average & t count & t table & P \\
\cline { 1 - 2 } Open Ended Approach & 80.38 & \multirow{2}{*}{6,641} & \multirow{2}{*}{1,998} & 0.000 \\
\hline Ordinary Learning & 63.53 & & & \\
\hline
\end{tabular}

Based on the table above, the average value of the mathematical reasoning ability of the Open Ended approach class is 80.38 and the average value of the mathematical reasoning ability of the ordinary learning class is 63.53, so there is a difference of 16.85. It was also found that $t$ count $>t$ table at a significance level of $5 \%$ $(6.641>1.998)$ and had a $\mathrm{p}$ value of $<0.05$ which means $\mathrm{H} 0$ was rejected so that it can be concluded that the mathematical reasoning ability of students who were given an Open Ended learning approach was higher than the reasoning ability. Mathematics students who are given ordinary learning at SMP Ikhwanul Muslimin Medan so that there are differences in the mathematical reasoning abilities taught by the Open Ended approach with mathematical reasoning abilities taught by ordinary learning.

2. Mathematical Critical Thinking Ability t-test

The summary of the t-test of critical thinking skills taught with the Open Ended approach with critical thinking 
skills with ordinary learning is shown in Table 4.46. following:

Table 1.4. Summary of Mathematical Critical Thinking Ability t Test Results Summary

\begin{tabular}{|l|c|c|c|c|}
\hline \multicolumn{1}{|c|}{ Class } & Average & t count & t table & P \\
\cline { 1 - 2 } Open Ended Approach & 76.38 & \multirow{2}{*}{4,997} & \multirow{2}{*}{1,998} & \multirow{2}{*}{0.000} \\
\hline Ordinary Learning & 65.00 & & \\
\hline
\end{tabular}

Based on Table 4.46. above, the average value of mathematical critical thinking skills for the Open Ended approach class is 76.38 and the average value of mathematical critical thinking skills for ordinary learning classes is 65.00 so that there is a difference of 11.38. It is also found that $t$ count $>t$ table at a significance level of $5 \%(4.997>1.998)$ and has a $\mathrm{p}$ value $<0.05$ which means $\mathrm{H} 0$ is rejected so it can be concluded that the mathematical critical thinking ability of students who are given learning based on the Open Ended approach is higher than the ability to think critically. mathematical critical thinking of students who are given ordinary learning at SMP Ikhwanul Muslimin Medan so that there is a difference in mathematical critical thinking skills taught with the Open Ended approach with mathematical critical thinking skills taught with ordinary learning.

\section{RESEARCH DISCUSSION}

Based on the formulation of the problem and research questions posed in the previous section, then based on the data obtained from the results of trials 1 and 2 it will be known whether the formulation of the problem and the research questions posed have been answered or not. The results of data analysis obtained from the results of trials 1 and 2 show:(1) there are improving students' mathematical reasoning skills using learning videos with an Open Ended approach; (2) there areimproving students' mathematical critical thinking skills using learning videos with an Open Ended approach; and (3)Learning videos with the Open Ended approach have been effective in improving students' mathematical reasoning and critical thinking skills (4) there are the differences in students' mathematical reasoning and thinking abilities who are taught using learning videos with an Open Ended approach with students' mathematical reasoning and critical thinking abilities taught using ordinary learning.

\section{BIBLIOGRAPHY}

Afifah, IN Sudargo., Prasetyowati, D. (2019). The Effectiveness of Problem Based Learning and Think Talk Write Models on the Mathematics Problem Solving Ability of Junior High School Students. Imaginary: Journal of Mathematics and Mathematics Education. 1(5). 157-163.

Hasratuddin. (2018). Why Should You Learn Maths. Medan: Perc. Edira.

Kurniasih, AW (2012). Scaffolding as an Alternative Efforts to Improve Mathematical Critical Thinking Ability. Kreano Journal. 3(2):113-124.

National Council of Teachers of Mathematics. (2000). Principles and Standards for School Mathematics. Reston. VA: NCTM.

Novitar, C., \& Aripin, U. (2017). Improving Mathematical Critical Thinking Ability and Confidence of Junior High School students through an Open Ended Approach. Prism: 6 (2).

Rizqi, NR, Surya, E. (2017). An Analysis Of Students' Mathematical Reasoning Ability In VIII Grade Of Sabilina Tembung Junior High School. IJARIIE, 3(2).https://www.researchgate.net/publication/318562729.

Sawada, T. (1997). Developing Lesson Plans. In Shimada, S and Becker JP (editor) The Open-Ended Approach a New Proposal for Teaching Mathematics. Virginia: National Council of Teachers of Mathematics.

Simamora, RE, Saragih, S., \& Hasratuddin, H. (2018). Improving Students' Mathematical Problem Solving Ability and Self-Efficacy through Guided Discovery Learning in Local Culture Context. International Electronic Journal of Mathematics Education.https://doi.org/10.12973/iejme/3966.

Suryadi, A. (2005). Education, Human Resources Investment, and Development. Jakarta: Balai Pustaka.

Wondershare Filmora. (2019). Wondershare Video Editor at a glance.http://id.wondershare.com/videoeditor/guide.html, accessed December 30, 2020. 